\title{
Serum specific IgA antibody to Chlamydia trachomatis in patients with chlamydial infections detected by ELISA and an immunofluorescence test
}

\author{
R CEVENINI, ${ }^{*}$ I SAROV,$\S$ F RUMPIANESI, ${ }^{*}$ M DONATI, ${ }^{*}$ C MELEGA, $\dagger$ C VAROTTI, $\ddagger$ \\ M LA PLACA*
}

From the *Institute of Microbiology, †Department of Reproductive Physiopathology, $¥$ Institute of

Dermatology, University of Bologna, School of Medicine, Ospedale S Orsola, 9 Via Massarenti, 40138

Bologna, Italy; and the §Department of Virology, Faculty of Health Sciences, Ben Gurion University of the

Negev, Beer Sheva, Israel

SUMMARY Sera obtained from 34 men with Chlamydia trachomatis positive non-gonococcap urethritis, 34 men with $C$ trachomatis negative non-gonococcal urethritis, 42 women with acute salpingitis, 38 healthy women, and 34 healthy men were studied for the presence of specific serum $C$ trachomatis IgA and IgG antibodies. Serological results were correlated with $C_{\overparen{D}}$ trachomatis isolation in cell culture.

An enzyme linked immunosorbent assay (ELISA) for $C$ trachomatis specific serum IgA waso employed using highly purified elementary bodies of $C$ trachomatis serotype L 2 grown in LLC: MK2 cells. Results obtained for $C$ trachomatis IgA antibody by the ELISA test were compare with results obtained for the same sera by a single antigen immunofluoresence technique. A good correlation $(r=0.91)$ was found between two methods. Serum IgG antibody was also determinec, in the same sera by the immunofluorescence technique.

Patients with $C$ trachomatis positive non-gonococcal urethritis had a significantly $(\mathrm{p}<0.0005) \stackrel{\mathbb{\Omega}}{\stackrel{\Omega}{\Omega}}$ higher prevalence $(94.1 \%)$ of serum IgA antibody by ELISA compared with patients with $C_{3}^{0}$ trachomatis negative non-gonococcal urethritis $(20.5 \%)$ or healthy men $(5.9 \%)$. Similarly women with acute salpingitis had a significantly $(\mathrm{p}<0.005)$ higher prevalence of serum IgAO antibody $(45 \cdot 2 \%)$ compared with healthy controls $(5 \cdot 2 \%)$. Comparable results were obtained for $C$ trachomatis serum IgA antibody using the immunofluorescence technique.

The prevalence of $C$ trachomatis IgG antibody was significantly higher in patients with $C$. trachomatis positive non-gonococcal urethritis $(97.0 \%)$ compared with those with $C$ trachomatis negative non-gonococcal urethritis $(33 \cdot 3 \%)$ and healthy controls $(23 \cdot 5 \%)$. A significantly $(p<\beta$ $0.05)$ higher prevalence of serum IgG antibody was also found in women with acute salpingitis $(52.4 \%)$ compared with healthy controls $(26 \cdot 3 \%)$.

The importance of using specific $C$ trachomatis serum $\operatorname{IgA}$ in the identification of chlamydia? infection is discussed.

Chlamydia trachomatis is now generally considered the most common sexually transmitted agent. In addition to its recognised role in urethritis, cervicitis, salpingitis, proctitis, conjunctivitis, and pneumonia, ${ }^{1-4}$ subclinical infections by $C$ trachomatis appear to be a major cause of infertility in women. ${ }^{56}$

The diagnosis of chalmydial infection is generally made after isolation in cell culture. Reliable cul-

Accepted for publication 13 February 1984 tures, however, are generally available only in large medical centres with extensive experience in tissue culture techniques.

The microimmunofluorescence test of Wang and Grayston 7 has been shown to be both sensitive and specific for the detection of chlamydial antibodies Efforts to simplify the test have entailed the use of $\overline{6}$ single broadly reacting antigen, usually $L 2$. .D $^{\circ}$ Serotype E or serotype $\mathbf{L} 2$ have also been used in single antigen immunofluorescence assay. ${ }^{10}$

More recently, the detection of chlamydial anti 
bodies by enzyme linked immunosorbent assay (ELISA), ${ }^{11-13}$ radioimmunoassay, ${ }^{14}$ and immunoperoxidase assay ${ }^{15}$ has been described.

To date, little is known about the role of serum IgA antibodies in chlamydial and viral infections. With regard to viral infection, several studies ${ }^{16-21}$ have suggested that specific $\operatorname{IgA}$ antibody may be an indicator of an active infection.

In order to verify the feasibility of determining $C$ trachomatis specific IgA serum antibody as an additional test for patients with chlamydial infections, a single antigen enzyme linked immunosorbent assay was adapted for specific $C$ trachomatis serum $\operatorname{IgA}$ and compared with an immunofluorescence test. Serum IgG detection by an immunofluorescence technique was also performed on the same sera. Serological results were correlated with $C$ trachomatis isolation in cell culture.

\section{Material and methods}

\section{STUDY POPULATION}

Serum samples and urethral or cervical cultures for $C$ trachomatis were obtained from patients included in a multicentre study of sexually transmitted diseases. These included 34 men (mean age 25.4 years) with $C$ trachomatis positive non-gonococcal urethritis, 34 men (mean age 24.4 years) with $C$ trachomatis negative non-gonococcal urethritis, and 42 women (mean age 28.3 years) with acute salpingitis. The clinical diagnosis of acute salpingitis was based on common criteria, which included lower abdominal pain, abnormal vaginal discharge, adnexal tenderness, erythrocyte sedimentation rate $\geqslant 15 \mathrm{~mm}$ in the first hour, and usually fever $\left(\geqslant 38^{\circ} \mathrm{C}\right)$.

Thirty eight healthy women (mean age $27 \cdot 2$ years) and 34 healthy men (mean age 26 years) were also studied. Cultures for $C$ trachomatis were not obtained from these two population groups.

Ten sera from children negative by the immunofluorescence test for serum $\operatorname{IgA}$ to $C$ trachomatis were used as negative controls in the ELISA test.

CHLAMYDIAL ANTIGEN AND ELISA PROCEDURE The LLC-MK2 cell line derived from monkey kidney cells was used for growing $C$ trachomatis. The cells (which are highly susceptible to $C$ trachomatis) were grown in $75 \mathrm{~cm}^{3}$ tissue culture flasks with Eagle's minimum essential medium containing $10 \%$ fetal calf serum and $10 \mu \mathrm{g} / \mathrm{ml}$ gentamicin. When confluent monolayers had formed, the medium was replaced with the same medium containing $5 \%$ fetal calf serum, $10 \mu \mathrm{g} / \mathrm{ml}$ gentamicin, $1 \mu \mathrm{g} / \mathrm{ml}$ cycloheximide, and $30 \mu \mathrm{M}$ glucose. LLC-MK2 cell mono- layers were infected with $C$ trachomatis serotype $\mathrm{L} 2$ (434-BU strain, provided by J Schachter, San Francisco, California). The infected cultures were incubated at $37^{\circ} \mathrm{C}$ for $48 \mathrm{~h}$.

Elementary bodies of $C$ trachomatis were purified by the method of Caldwell et al, ${ }^{22}$ by Renografin gradients, with minor modifications. Briefly, infected cells were ruptured by sonication and centrifuged. The supernatant was layered over $8 \mathrm{ml}$ of a $35 \%$ (vol/vol) Renografin (ER Squibb and Sons Inc, Princeton, New Jersey, USA) solution in $0.01 \mathrm{M}$ HEPES and centrifuged at $43000 \mathrm{~g}$ for $1 \mathrm{~h}$ at $4^{\circ} \mathrm{C}$ in a SW 27 rotor (Beckman Instruments Inc, Fullerton, California.) The pellet was resuspended in $0.01 \mathrm{M}$ sodium phosphate $(\mathrm{pH} \mathrm{7 \cdot 2)}$ and layered over discontinuous Renografin gradients $(13 \mathrm{ml}$ of $40 \%, 8 \mathrm{ml}$ of $44 \%$, and $5 \mathrm{ml}$ of $52 \%$ Renografin, vol/vol), centrifuged at $43000 \mathrm{~g}$ for $1 \mathrm{~h}$ at $4^{\circ} \mathrm{C}$ in a SW 27 rotor. The elementary body band was collected by Pasteur pipette, diluted in 0.01 M HEPES, and then centrifuged at $30000 \mathrm{~g}$ for $30 \mathrm{~min}$. The protein content of preparations was determined by the method of Lowry et al. ${ }^{23}$

Control antigen was prepared in the same way from uninfected LLC-MK2 cells.

Micro ELISA plates (Dynatech M129A) were coated with $100 \mu \mathrm{l}$ of elementary bodies or control antigen in carbonate-bicarbonate buffer $\mathrm{pH} 9.6$ for $1 \mathrm{~h}$ at room temperature. The final protein concentration of elementary body or control antigen preparations was $20 \mu \mathrm{g} / \mathrm{ml}$. Coated plates were washed five times with phosphate buffered saline (PBS)Tween (Sigma Chemical, St Louis, Missouri) and used immediately. Serial twofold dilutions of human sera in PBS-Tween were made in the test plate. Each serum dilution was tested in elementary body and control antigen coated wells. A known positive and one negative serum sample were assayed on each plate. The plate was then incubated at $37^{\circ} \mathrm{C}$ for $1 \mathrm{~h}$ and washed 10 times with PBSTween. Antihuman IgA ( $\alpha$-chain) peroxidase labelled (Dako, Copenhagen, Denmark) diluted $1 / 400$ in PBS-Tween was added in a volume of $100 \mu \mathrm{l}$ per well. The plate was incubated for $1 \mathrm{~h}$ at $37^{\circ} \mathrm{C}$, washed 10 times with PBS-Tween. Thereafter, 100 $\mu \mathrm{l}$ of the citric acid phosphate buffer ( $\mathrm{pH} \mathrm{5.6)} \mathrm{con-}$ taining $40 \mathrm{mg} 1.2$ phenylendiaminedihydrochloride (Merck, Darmstadt, West Germany) and $20 \mu \mathrm{l}$ of $30 \% \mathrm{H}_{2} \mathrm{O}_{2}$ per $100 \mathrm{ml}$ buffer was added per well. The enzymatic reaction was stopped after $15 \mathrm{~min}$ by adding $100 \mu \mathrm{l}$ of $2 \mathrm{~N} \mathrm{H}_{2} \mathrm{SO}_{4}$ per well. The result of the test was read at $492 \mathrm{~nm}$ by a Dynatech Microelisa autoreader MR, 580. All readings were made against a blank well, which received all of the above treatments except that human serum was replaced by PBS-Tween. 
The reproducibility of the results was in the range of twofold dilutions.

\section{IMMUNOFLUORESCENCE TEST}

All sera were tested for chlamydial antibodies of the IgG and IgA classes by a single antigen test using the L2 strain of $C$ trachomatis inclusions in LLC-MK2 cells, as previously described. ${ }^{9}$ Fluorescein labelled antihuman IgG or IgA antibodies (Dako) and dilutions of $1 / 40$ or $1 / 10$ respectively were used.

\section{CHLAMYDIAL CULTURES}

Isolation of $C$ trachomatis from clinical specimens was done in McCoy cells, which were pretreated with $5^{\prime}$-iodo-2'-deoxyuridine as previously described. ${ }^{9}$

\section{STATISTICAL ANALYSIS}

Statistical significance was evaluated by the $\chi^{2}$ test with Yates's correction, or by Student' $s t$ test.

\section{Results}

\section{STANDARDISATION OF ELISA FOR}

DETERMINATION OF C TRACHOMATIS IgA

An optimal concentration of $20 \mu \mathrm{g} / \mathrm{ml}$ for elementary bodies was used for coating the microtitre plate. At this antigen concentration serial twofold dilutions (from 1/80 to $1 / 512$ ) of high, medium, and low

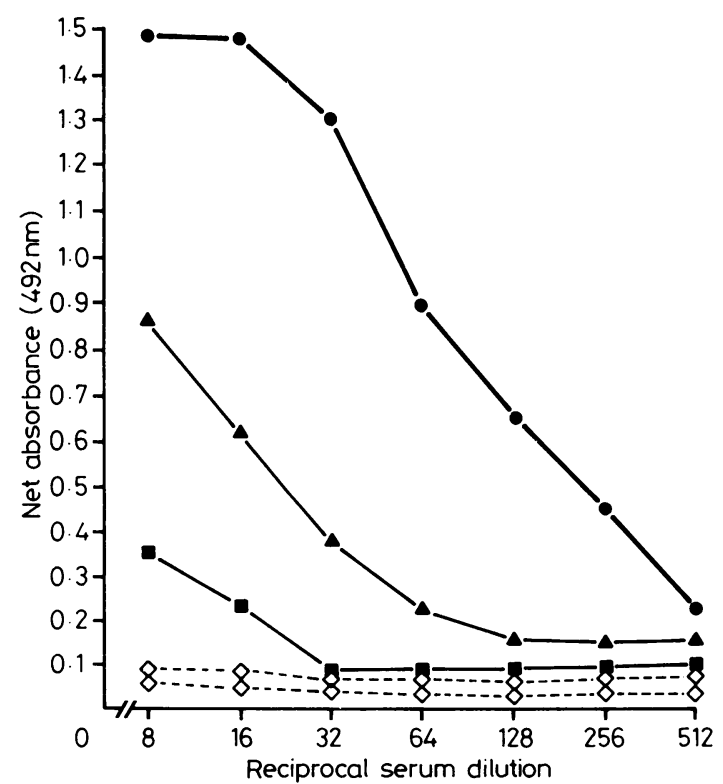

Fig. 1 Titration curves for serum chlamydial IgA antibody by ELISA. Results from high positive $(\bullet)$, intermediate positive $(\mathbf{\Delta})$, low positive $(\mathbf{\square})$, and two negative sera $(\diamond)$ are shown. positive sera showed a linear relation to absorbance $\frac{0}{3}$ (Fig. 1).

Antibody titres were expressed as the reciprocal of the highest serum dilution that yielded an optical $\stackrel{\text { क }}{+}$ density at $492 \mathrm{~nm}>5$ standard deviations over the mean of values obtained with sera from 10 children negative by immunofluorescence for serum IgA to $C \frac{\bar{\sigma}}{\vec{D}}$ trachomatis, and tested by ELISA in a separate $\varrho$ experiment. The IgA antibody titres ranged from $8 \%$ to 512 .

The titration results for all sera tested with ELISA and immunofluorescence tests are shown in Fig. 2. $\vec{\omega}$ Of the 182 sera tested 120 were negative and 59 ? were positive by both techniques. Three sampleso were positive by ELISA and negative by the immunofluorescence test (see below).

The correlation coefficient for IgA with the two methods was 0.91 , showing good agreement.

C TRACHOMATIS IgA ANTIBODY

Antichlamydial serum $\operatorname{IgA}$ antibody was found by ELISA in $32(94 \cdot 1 \%)$ of 34 men with $C$ trachomatis $\overparen{D}$ positive non-gonococcal urethritis, with a mean titre $\vec{\theta}$ of $24 \cdot 8$, whereas only seven $(20.5 \%)$ of 34 men with $\underset{+}{\infty}$ $C$ trachomatis negative non-gonococcal urethritis $\left(\mathrm{p}_{\square}\right.$ $<0.0005)$ had IgA serum antibody with a mean titre of $28 \cdot 7$. Only two $(5 \cdot 9 \%)$ of 34 healthy controls had serum IgA to $C$ trachomatis.

Women with acute salpingitis had a significantly $(p<0.005)$ higher prevalence of $C$ trachomatis $\operatorname{IgA}$

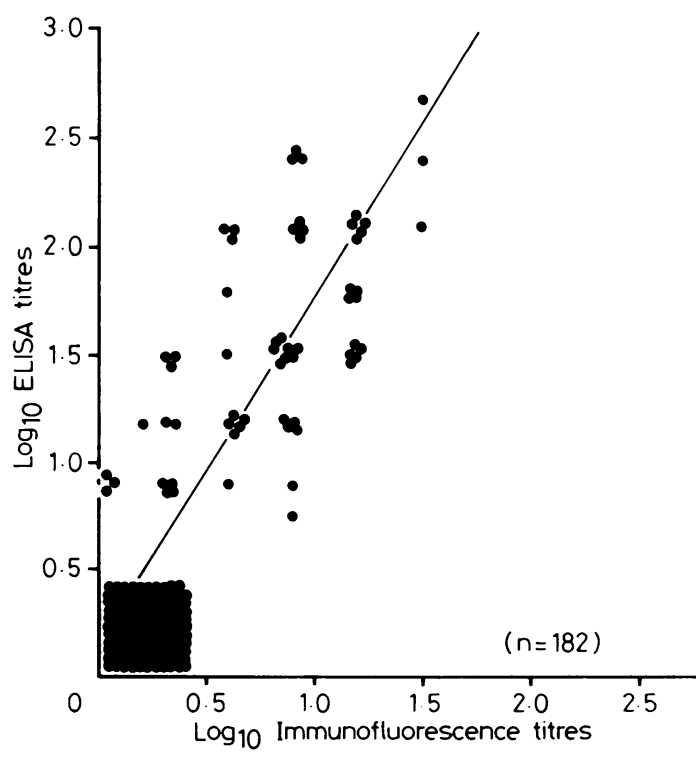

Fig. 2 Correlation between antibody titres obtained by ELISA and the immunofluorescence test $(n=182 ; y=$ $1.58 \times+0.085 ; r=0.91)$. 
antibodies compared with control women: 19 $(45.2 \%)$ of 42 women with acute salpingitis and two $(5.2 \%)$ of 38 healthy women were positive for serum IgA to $C$ trachomatis. The mean titre of $\operatorname{IgA}$ seropositive patients with acute salpingitis was 54.4. Of the 42 women with acute salpingitis, three (7.1\%) had positive cervical cultures for $C$ trachomatis. All three patients had serum $\operatorname{IgA}$ to $C$ trachomatis with high titres ranging from 64 to 128 . Comparable results were obtained by the immunofluorescence technique.

\section{TRACHOMATIS IgG ANTIBODY}

Patients with $C$ trachomatis positive non-gonococcal urethritis had a significantly ( $p<0.0005)$ higher prevalence of $C$ trachomatis IgG seropositivity than healthy controls ( $97.0 \%$ and $23.5 \%$ respectively). A higher prevalence of $C$ trachomatis IgG antibody was also found in patients with $C$ trachomatis negative non-gonococcal urethritis compared with healthy controls $(33.3 \% \vee 23.5 \%)$, but this difference was not significant.

A significantly $(\mathrm{p}<0.05)$ higher prevalence of $C$ trachomatis IgG antibodies was also found in patients with acute salpingitis compared with controls $(52.4 \% v 26.3 \%)$ (Table).

\section{Discussion}

The feasibility of the ELISA technique for chlamydial serology has been shown previously. ${ }^{11-13}$ We have developed an ELISA test in which the elementary bodies of $C$ trachomatis L2 serotype were used as antigen for the detection of specific serum IgA antibodies to $C$ trachomatis in human serum. The results obtained by ELISA were compared with those obtained by the immunofluorescence technique: a positive correlation $(r=0.91)$ was found. Higher titres were obtained by ELISA than by immunofluorescence. With only three exceptions, however, (three samples positive by ELISA and negative by the immunofluorescence technique) there was agreement as far as IgA serpositivity and IgA seronegativity was concerned.

Two infections which can be caused by $C$ trachomatis have been considered in this study: acute salpingitis in women and non-gonococcal urethritis in men. Recent investigations ${ }^{34-26}$ have shown that $C$ trachomatis can be associated with acute salpingitis. The relative importance of $C$ trachomatis as a cause of acute salpingitis varies greatly depending on the population, ranging between 5 and $36 \%$ and 20 and $62 \%$ when cultural or serological ${ }^{25} 27$ data respectively are considered.

In the current study $C$ trachomatis IgG antibodies were determined by the indirect immunofluorescence technique and IgA antibodies were determined by both ELISA and the immunofluorescence technique.

Women with acute salpingitis had a significantly higher prevalence $(\mathrm{p}<0.05)$ of $C$ trachomatis IgG antibodies compared with matched controls (52.4\% $v 26.3 \%)$. The mean IgG titre $(82 \cdot 0)$ of the patients with acute salpingitis was significantly $(p<0.05)$ higher than that of controls $(13 \cdot 1)$. Relatively high $C$ trachomatis IgG titres $(\geqslant 64)$ were noted in $30.9 \%$ of the acute salpingitis group, and none of the healthy controls had IgG titres $\geqslant 64$. These results are in agreement with previous studies using microimmunofluorescence techniques ${ }^{28} 29$ in which a higher prevalence of raised IgG titres was found in patients with acute salpingitis compared with controls. $C$ trachomatis IgG titres $\geqslant 64$ by the microimmunofluorescence technique have been suggested to be associated with current chlamydial infection..$^{28} C$ trachomatis IgG antibody, however, may indicate only previous chlamydial infection in sites other than the fallopian tube.

We have shown by both ELISA and the immunofluorescence technique a higher prevalence

Prevalence of serum IgA antibody to C trachomatis detected both by ELISA and by an immunofuorescence technique compared with chlamydial IgG antibody detected by an immunofuorescence test in different study populations

\begin{tabular}{|c|c|c|c|c|c|c|c|c|c|c|c|c|c|}
\hline \multirow[t]{2}{*}{ Study group } & \multirow{2}{*}{$\begin{array}{l}\text { No } \\
\text { tested }\end{array}$} & \multicolumn{4}{|c|}{$I g A E L I S A$} & \multicolumn{4}{|c|}{ IgA IFA test } & \multicolumn{4}{|c|}{ IgG IFA test } \\
\hline & & $\begin{array}{l}\text { No } \\
\text { Positive }\end{array}$ & $(\%)$ & $\begin{array}{l}\text { Mean } \\
\text { titre }\end{array}$ & $\begin{array}{l}\text { Titre } \\
\geqslant 32 \\
(\%)\end{array}$ & $\begin{array}{l}\text { No } \\
\text { Positive }\end{array}$ & $(\%)$ & $\begin{array}{l}\text { Mean } \\
\text { titre }\end{array}$ & $\begin{array}{l}\text { Titre } \\
\geqslant 16 \\
(\%)\end{array}$ & $\begin{array}{l}\text { No } \\
\text { Positive }\end{array}$ & $(\%)$ & $\begin{array}{l}\text { Mean } \\
\text { titre }\end{array}$ & $\begin{array}{l}\text { Titre } \\
\geqslant 64 \\
(\%)\end{array}$ \\
\hline $\begin{array}{l}\text { Men with NGU Ch+ } \\
\text { Men with NGU Ch- } \\
\text { Healthy men } \\
\text { Women with AS } \\
\text { Healthy women }\end{array}$ & $\begin{array}{l}34 \\
34 \\
34 \\
42 \\
38\end{array}$ & $\begin{array}{r}32 \\
7 \\
2 \\
19 \\
2\end{array}$ & $\begin{array}{l}(94 \cdot 1) \\
(20 \cdot 5) \\
\left(\begin{array}{r}5 \cdot 9) \\
(45 \cdot 2) \\
(5.2)\end{array}\right.\end{array}$ & $\begin{array}{l}24 \cdot 8 \\
28 \cdot 7 \\
12 \cdot 5 \\
54 \cdot 4 \\
15 \cdot 8\end{array}$ & $\begin{array}{l}41 \cdot 6 \\
14 \cdot 7 \\
-35 \cdot 7 \\
-\end{array}$ & $\begin{array}{r}31 \\
5 \\
2 \\
19 \\
2\end{array}$ & $\begin{array}{l}(91 \cdot 2) \\
(14 \cdot 7) \\
(5 \cdot 9) \\
(45 \cdot 2) \\
(5 \cdot 2)\end{array}$ & $\begin{array}{c}5 \cdot 5 \\
4 \cdot 8 \\
2 \cdot 8 \\
12 \cdot 3 \\
4\end{array}$ & $\begin{array}{l}14 \cdot 2 \\
14 \cdot 2 \\
\frac{21 \cdot 4}{-}\end{array}$ & $\begin{array}{r}33 \\
11 \\
8 \\
22 \\
10\end{array}$ & $\begin{array}{l}(97 \cdot 0) \\
(33 \cdot 3) \\
(23.5) \\
(52 \cdot 4) \\
(26.3)\end{array}$ & $\begin{array}{l}28 \cdot 0 \\
16 \cdot 9 \\
12 \cdot 1 \\
82 \cdot 0 \\
13 \cdot 1\end{array}$ & $\begin{array}{r}30 \cdot 4 \\
9 \cdot 1 \\
- \\
30 \cdot 9 \\
-\end{array}$ \\
\hline
\end{tabular}

NGU Ch+ $=C$ trachomatis positive non-gonococcal urethritis.

NGU Ch- $=C$ trachomatis negative non-gonococcal urethritis.

AS = acute salpingitis.

IFA $=$ immunofluorescence. 
and raised $C$ trachomatis IgA antibody titres in patients with acute salpingitis compared with matched controls. By the ELISA technique, patients with acute salpingitis showed a significantly $(p<$ 0.005 ) higher prevalence of IgA antibodies to $C$ trachomatis than the control group $(45.2 v 5.2 \%)$. The mean IgA titre of women with acute salpingitis by the same technique was significantly $(p<0.01)$ higher than that in controls $(54.4 v 15.8)$. Relatively high $C$ trachomatis IgA titres $(\geqslant 32)$ were found in $35.7 \%$ of patients with acute salpingitis, while none of the control group had IgA titres $\geqslant 32$. Similar results were also obtained by the immunofluorescence technique.

Since the half life of $C$ trachomatis $\operatorname{IgA}$ was five to six days in normal subjects ${ }^{27}$ the presence of these antibodies may be a better marker for active $C$ trachomatis infection than $C$ trachomatis IgG antibody. Confirmation of this will require relating the presence of $C$ trachomatis serum IgA antibody with the isolation of the agent from the fallopian tube.

The availability of a serological marker of $C$ trachomatis infection in patients with acute salpingitis would be of considerable value and might obviate the need for invasive procedures in the diagnosis of acute salpingitis.

A clear cut association between $C$ trachomatis specific serum IgA and active $C$ trachomatis infection was found in men with $C$ trachomatis positive non-gonococcal urethritis. Of these, $94.1 \%$ had $C$ trachomatis serum IgA compared with only $20.5 \%$ of $C$ trachomatis negative non-gonococcal urethritis patients $(p<0.0005)$ and $5.9 \%$ of healthy subjects $(p<0.0005)$. Ninety seven per cent of $C$ trachomatis positive non-gonococcal urethritis patients also had serum IgG compared with $33.3 \%$ of $C$ trachomatis negative non-gonococcal urethritis patients $(p<0.0005)$ and $23.5 \%$ of healthy men.

In a previous study, Thero and Meurman, ${ }^{14}$ using a radioimmunoassay technique, found serum IgA in only $53 \%$ of isolation positive as against $21 \%$ isolation negative men with urethritis. The different results obtained in the current study can be tentatively explained both by the different population examined and by the methods used. In this study specific $C$ trachomatis IgA antibody was always found in association with serum IgG antibody: the higher the IgG titre the higher the $\operatorname{IgA}$ titre, the highest IgA titres being found in patients with acute salpingitis. In $C$ trachomatis positive non-gonococcal urethritis patients serum $\operatorname{IgA}$ was also found in the presence of low (16-32) IgG titres.

In conclusion, the presence of serum IgA antibody to $C$ trachomatis seems to be correlated with active $C$ trachomatis infection, at least in patients with chlamydial non-gonococcal urethritis. Hence,
IgA detection may be a useful further test in $\stackrel{0}{\vec{\sigma}}$ chlamydial serology. However, the possibility that $C$ 을 trachomatis serum IgA can be used as a marker of a $\overrightarrow{\vec{D}}$ current $C$ trachomatis infection needs further inves- $\stackrel{\oplus}{?}$ tigation. The appearance and persistence of $C$ 듬 trachomatis IgA have to be examined in prospective $\frac{\bar{\sigma}}{\bar{c}}$ studies and correlated wth the development of $\frac{\vec{\sigma}}{\sigma}$ symptomatic or asymptomatic $C$ trachomatis infec- $\varrho$ tions.

This work was supported by Italian National Council for Scientific Research (CNR) grant no $\vec{\omega}$ 82.02759.04 and in part by the Meaddle East Eye $\frac{\text { ? }}{8}$
Research Institute (MEERI).

We thank Mr L Franchi and Mr V Sambri for excellent technical work and Mrs Valeria Zagnoli for typing the manuscript.

\section{References}

' Hilton AL, Richmond SJ, Milna JD, Hindley F, Clarke SKR. Chlamydia $A$ in the female genital tract. Br $J$ Vener Dis $\overrightarrow{0}$ 1974;50:1-10.

${ }^{2}$ Holmes KK, Handsfield HH, Wang SP. et al. Etiology of non- $\stackrel{\varnothing}{+}$ gonococcal urethritis. N Engl J Med 1975;292:1199-205.

${ }^{3}$ Mardh PA, Ripa T, Svennsson L, Westrom L. Chlamydia trachomatis infection in patients with acute salpingitis. $N$ Engl J Med 1977;296:1377-9.

${ }^{4}$ Schachter J, Grossman M. Chlamydial infections. Ann Rev Med $1981 ; 32: 45-61$.

5 Jones RB, Andrey BR, Hui SL, Cleary RE. Correlation between $\stackrel{\mathbb{Q}}{2}$ serum antichlamydial antibodies and tubal factor as a cause of $\overrightarrow{\overrightarrow{\hat{D}}}$ infertility. Fertil Steril 1982;38:553-8.

- Cevenini R, Possati G, La Placa M. Chlamydia trachomatis infection in infertile women. In: Mardh PA, Holmes KK, Oriel JD, Piot P, Schachter J, eds. Chlamydial infections. New York, Oxford: Elsevier Biomedical Press, 1982:189-92.

' Wang SP, Grayston JT. Immunological relationship between? genital TRIC lymphogranuloma venereum and related organ- $\frac{O}{3}$ isms in a new microtiter indirect immunofluorescence test Am J Ophthalmol 1970; 70:367-74.

${ }^{8}$ Thomas BJ, Reeve P, Oriel JD. Simplified serological test for antibodies to Chlamydia trachomatis. J Clin Microbiol 1976;4:6-10.

Cevenini R, La Placa M. Chlamydial infections in Italy. Sex Trans Dis 1981;8:349-52.

${ }^{10}$ Saikku P, Paavonen J. Single antigen immunofluorescence test for chlamydial antibodies. J Clin Microbiol 1978;8:119-22. N

" Cevenini R, Donati M, Rumpianesi F. Elementary bodies as" single antigen in a micro-ELISA test for Chlamydia N trachomatis. Microbiologica 1981;4:347-51.

12 Jones RB, Bruins SC, Newhall WJ. Comparison of reticulate body antigens in detection of antibodies against Chlamydia trachomatis by enzyme-linked immunosorbent assay. J Cline Microbiol 1983; 17:466-71.

${ }^{13}$ Evans RT, Taylor-Robinson D. Development and evaluation of an enzyme-linked immunosorbent assay (ELISA) using chlamydial group antigen, to detect antibodies to Chlamydiatrachomatis. J Clin Pathol 1982;35:1122-8.

14 Thero P, Meurman O. Chlamydial serum IgG, IgA and local IgA antibodies in patients with genital tract infections measured by solid phase radioimmunoassay. J Med Microbiol 1981;14:77-87.

is Cevenini R, Rumpianesi F, Donati M, Sarov I. A rapid 
immunoperoxidase assay for the detection of specific IgG antibodies to Chlamydia trachomatis. J Clin Pathol 1983;36:353-6.

${ }^{16}$ Evans AS, Niederman JC. EBV-IgA and new heterophile antibody tests in diagnosis of infectious mononucleosis. AJCP 1982;77:555-60.

17 Ho HC, Ng MH, Kwan HC, Chan JWC. Epstein-Barr virus specific IgA and IgG serum antibodies in nasopharyngeal carcinoma. Br J Cancer 1976;34:655-9.

18 Hornsleth A, Leerhoy J, Grauballe P, Spanggard H. Persistence of rubella virus specific immunoglobulin $M$ and $A$ antibodies: Investigation of successive serum samples with lowered immunoglobulin G concentration. Infect Immun 1975; 11:804-8

${ }^{19}$ Levy E, Sarov I. Detection of specific IgA antibodies in serum of patients with varicella and zoster infections. Intervirology 1980;15:103-10.

${ }^{20}$ Nikoskelainen J, Neel EU, Stevens DA. Epstein-Barr virus specific serum immunoglobulin $A$ as an acute phase antibody in infectious mononucleosis. J Clin Microbiol 1979;10:75-9.

${ }^{21}$ Sarov I, Levy E, Aymard M, et al. Detection of virus specific IgA antibodies in serum of kidney transplant patients with recurrent cytomegalovirus infection by enzymeimmuno- and radioimmunoassay techniques. Clin Exp Immunol 1982;48:321-8.

${ }^{22}$ Caldwell HD, Kromhout J, Schachter J. Purification and partial characterization of major outer membrane protein of
Chlamydia trachomatis. Infect Immun 1981;31:1161-76.

${ }^{23}$ Lowry OH, Rosebrough J, Farr AL, Randall RJ. Protein measurement with folin phenol reagent. J Biol Chem 1951;193:265-75.

${ }^{24}$ Rees E. Treatment of pelvic inflammatory disease. Am J Obstet Gynecol 1980;138: 1042-7.

${ }^{25}$ Sweet RL, Draper DL, Schachter J, James J, Hadley WK, Brooks GF. Microbiology and pathogenesis of acute salpingitis as determined by laparoscopy: what is the appropriate site to sample? Am J Obstet Gynecol 1980;138:985-9.

${ }^{26}$ Mardh PA, Lind I, Svennson L, Westrom L, Moller BR. Antibodies to Chlamydia trachomatis, Mycoplasma hominis and Neisseria gonorrhoeae in sera from patients with acute salpingitis. Br J Vener Dis 1981;57:125-9.

${ }^{27}$ Tomasi TB, Grey HM. Structure and function of immunoglobulin A. Progr Allergy 1972;16:81-113.

28 Treharne JD, Ripa KT, Märdh PA, Svennson L, Westrom L, Darougar S. Antibodies to $C$ trachomatis in acute salpingitis. Br J Vener Dis 1979;55:26-9.

${ }^{29}$ Moore DE, Foy HM, Daling JR, et al. Chlamydia trachomatis in infertility due to distal tubal diseases. Lancet 1982;ii: 574-7.

Requests for reprints to: Dr R Cevenini, Institute of Microbiology, Ospedale S. Orsola, 9 Via Massarenti, 40138 Bologna, Italy. 